\title{
Economic and Emission Dispatch pada Sistem Transmisi Jawa Bali 500 kV Berdasarakan RUPTL 2015 - 2024 Menggunakan Modified Artificial Bee Colony Algorithm
}

\author{
Dio Adya Pratama, Ontoseno Penangsang, Ni Ketut Aryani \\ Jurusan Teknik Elektro, Fakultas Teknologi Industri, Institut Teknologi Sepuluh Nopember (ITS) \\ Jl. Arief Rahman Hakim, Surabaya 60111 Indonesia \\ e-mail: dioadyapratama@gmail.com
}

\begin{abstract}
Abstrak-Biaya bahan bakar sebuah pembangkit termal merupakan fungsi beban pembangkit tersebut. Pada unit pembangkit termal, pertambahan beban akan mendorong pertambahan jumlah bahan bakar per satuan waktu dan pada akhirnya akan meningkatkan pertambahan biaya per satuan waktu. Selain itu, beban listrik merupakan fungsi biaya pembangkitan, maka perlu dicari solusi untuk mengoperasikan unit-unit pembangkit secara optimum dengan menekan biaya bahan bakar seminimum mungkin namun tetap memperhatikan constraint operasional. Selain itu, tiap pembangkit thermal yang beroperasi menghasilkan emisi Nitrogen dioksida $\left(\mathrm{NO}_{2}\right)$. Dengan demikian perlu adanya reduksi emisi yang dihasilkan oleh tiap pembangkit. Penggabungan kedua permasalahan di atas disebut dengan Economic and Emission Dispatch. Plant yang digunakan adalah kelistrikan pada sistem transmisi Jawa Bali 500 kV. Pada penelitian ini diaplikasikan Modified Artificial Bee Colony Algorithm (MABCA). Simulasi dilakukan dengan menggunakan weighting factor dan diketahui bahwa pada kondisi $W 1=1$ dan $W 2=0$, maka biaya pembangkitan memiliki nilai yang paling kecil namun memiliki emisi yang paling besar. Ketika $\mathrm{W} 1=0.5$ dan $\mathrm{W} 2=0.5$, maka biaya pembangkitan dan emisi akan sama-sama diprioritaskan. Jika $W 1=0$ dan $W 2=1$, maka biaya pembangkitan akan memiliki nilai paling besar, namun memiliki tingkat emisi yang paling kecil.
\end{abstract}

Kata Kunci-Economic and Emission Dispatch, weighting factor, constraint.

\section{PEndahuluan}

$\mathrm{K}$ ebutuhan tenaga listrik disuatu daerah secara terus menerus akan mengalami peningkatan sejalan dengan pembangunan dan kemajuan daerah tersebut. Kemajuan dan perkembangan teknologi dewasa ini mengakibatkan kebutuhan tenaga listrik akan semakin meningkat, baik yang berhubungan dengan listrik rumah tangga, komersil maupun industri. Sehingga dibutuhkan pasokan energi listrik yang akan terus meningkat. Untuk memenuhi kebutuhan energi listrik, perusahaan listrik harus menyediakan energi secara berkesinambungan.

Sistem tenaga listrik yang besar yang memiliki pembangkit-pembangkit termal seperti PLTU dan PLTG akan menghadapi permasalahan dalam hal biaya bahan bakar untuk pengoperasiannya. Oleh karena itu perlu dilakukan suatu upaya untuk mengurangi biaya operasi melalui pengurangan biaya bahan bakar sampai pada tingkat minimum. Metode untuk memproduksi dan mendistribusikan tenaga listrik secara ekonomis sedang dipelajari secara intensif oleh peneliti-peneliti yang berkecimpung dalam persoalan ini. Permasalahannya kemudian bagaimana mengatur pembebanan pembangkit listrik tersebut, sehingga jumlah energi listrik yang dibangkitkan sesuai dengan kebutuhan dan biaya produksi menjadi seminimal mungkin serta tetap memperhatikan tuntutan pelayanan. Cara yang dapat ditempuh adalah dengan melakukan koordinasi pembangkit-pembangkit termal dengan pembangkit hidro seperti PLTA, karena PLTA tidak membutuhkan biaya bahan bakar. PLTA dan pembangkit-pembangkit termal diinterkoneksi untuk melayani beban sistem. Dalam hal ini PLTA akan dioperasikan secara maksimum dan unitunit pembangkit termal dioperasikan setelah mencukupi kebutuhan tenaga listrik yang ada.

Pada tugas akhir ini akan digunakan salah satu teknik solusi masalah optimasi yaitu menggunakan teknik Modified Artificial Bee Colony Algorithm.

\section{ECONOMIC AND EMISSION DISPATCH}

\section{A. Sistem Tenaga Listrik}

Pada umumnya, sistem tenaga listrik dibagi menjadi tiga bagian utama. Ketiga bagian ini tidak dapat dipisahkan karena merupakan suatu sistem yang kompleks yang bekerja untuk menyalurkan daya dari pusat pembangkit ke pusat-pusat beban. Berikut penjelasannya :

\section{- Pusat Pembangkit Listrik (Power Plant)}

Pusat pembangkit listrik merupakan tempat pertama kali energi listrik dibangkitkan atau dihasilkan. Di sini terdapat turbin penggerak awal dan juga generator yang mengubah tenaga turbin menjadi energi listrik. Terdapat beberapa jenis pusat pembangkit listrik yang biasanya dibagi kedalam dua bagian besar yaitu pembangkit hidro (PLTA) dan pembangkit thermal (PLTU, PLTG, PLTGU, PLTD, PLTP).

- Transmisi Tenaga Listrik

Transmisi tenaga listrik merupakan proses penyaluran tenaga listrik dari pusat pembangkitan listrik hingga saluran distribusi listrik sehingga nantinya sampai pada konsumen/pengguna listrik.

- Sistem Distribusi

Sistem distribusi ini merupakan sub sistem tenaga listrik yang langsung berhubungan dengan 
pelanggan/konsumen dan berfungsi dalam hal pembagian atau penyaluran tenaga listrik ke beberapa tempat. Sub sistem ini terdiri dari : pusat pengatur / gardu induk, gardu hubung, saluran tegangan menengah/jaringan primer $(6 \mathrm{kV}$ dan $20 \mathrm{kV})$ yang berupa saluran udara atau kabel bawah tanah, saluran tegangan rendah / jaringan sekunder (380 V dan 220 $\mathrm{V})$, gardu distribusi tegangan yang terdiri dari panelpanel pengatur tegangan baik tegangan menengah ataupun tegangan rendah, dan trafo. (Joko et al, 2010:1-3)

\section{B. Karakteristik Input Output Pembangkit Termal}

Karakteristik ini memperlihatkan hubungan antara input pembangkit sebagai fungsi dari output pembangkit. Persamaan karakteristik input-output pembangkit menyatakan hubungan antara jumlah bahan bakar yang dibutuhkan untuk menghasilkan daya tertentu pada pembangkit listrik.

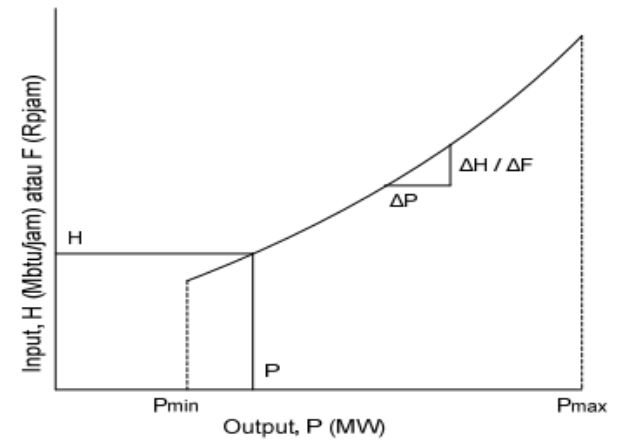

Gambar 1. Kurva Karakteristik Input-Output Unit Termal

Gambar diatas menunjukkan karakteristik input-output unit thermal dalam bentuk yang ideal, digambarkan sebagai kurva non-linier yang kontinu. Input dari pembangkit ditunjukkan pada sumbu tegak yaitu energi panas yang dibutuhkan dalam bentuk Mbtu/h karena digunakan satuan British Temperatur Unit (apabila menggunakan SI menjadi $\mathrm{MJ} / \mathrm{h}$ atau $\mathrm{Kcal} / \mathrm{H}$ ) yang dapat dinyatakan juga sebagai biaya total per jam (Rp/jam). Output dari pembangkit ditunjukkan pada sumbu mendatar yaitu daya listrik yang memiliki batas-batas berupa daya maksimum dan daya minimum pembangkit. (Saadat, 1999:267)

\section{Karakteristik Kenaikan Biaya/Panas Pembangkit Termal}

Karakteristik lain yang perlu untuk diketahui pada suatu pembangkit thermal adalah karakteristik laju panas atau incremental heat yang dapat juga dikatakan sebagai karakteristik kenaikan biaya. Karakteristik ini merupakan suatu kemiringan (slope) dari karakteristik input-output $(\Delta H / \Delta P$ atau $\Delta F / \Delta P)$ atau turunan pertama dari karakteristik input-output.

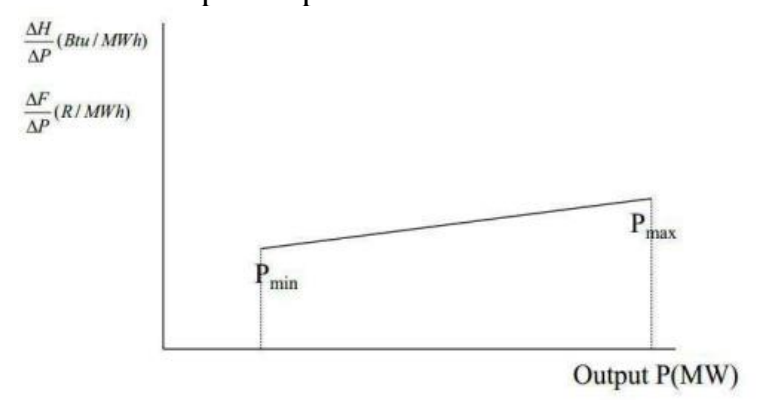

Gambar 2. Kurva Karakteristik Kenaikan Biaya/Panas Unit Termal
Pada karakteristik ini ditunjukkan nilai Btu per $\mathrm{kWh}$ atau $\mathrm{Rp} / \mathrm{kWh}$ terhadap daya keluaran dalam satuan MW. Lebih lanjutnya, karakteristik ini digunakan untuk perhitungan pembebanan ekonomis dari unit pembangkit. Jika persamaan input-ouput unit pembangkit dinyatakan dalam pendekatan dengan menggunakan persamaan kuadrat, maka karakteristik kenaikan biaya akan mempunyai bentuk garis lurus. (Saadat, 1999:267)

Karakteristik Efisiensi Terhadap Output Karakteristik laju panas juga salah satu karakteristik yang perlu diketahui. Pada karakteristik ini, input merupakan jumlah panas per kilowattjam (Btu/kWh) dan output merupakan daya listrik dalam satuan MW.

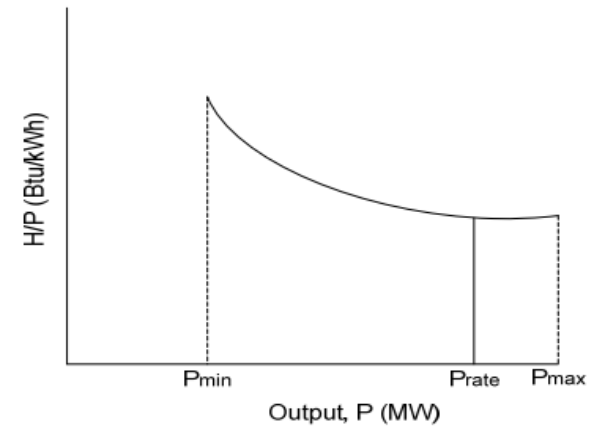

Gambar 3. Kurva Karakteristik Efisiensi Terhadap Output

Karakteristik laju panas ini menunjukan kerja sistem dari sistem pembangkit thermal seperti kondisi uap, temperatur panas, tekanan kondensor, dan siklus aliran air secara keseluruhan. Pada kurva terlihat bahwa efisiensi yang baik terletak pada limit maksimalnya. (Adrianti, 2010)

\section{Permasalahan Economic Dispatch}

Economic dispatch adalah pembagian pembebanan pada setiap unit pembangkit sehingga diperoleh kombinasi unit pembangkit yang dapat memenuhi kebutuhan beban dengan biaya yang optimum atau dengan kata lain untuk mencari nilai optimum dari output daya dari kombinasi unit pembangkit yang bertujuan untuk meminimalkan total biaya pembangkitan dan dapat memenuhi batasan equality dan inequality. Secara umum fungsi biaya dari tiap pembangkit dapat diformulasikan secara matematis sebagai suatu fungsi obyektif seperti yang diberikan pada persamaan berikut :

$F_{T}=\sum_{i=1}^{N} F_{i}\left(P_{i}\right)$

$F C_{i}\left(P_{i}\right)=a_{i} P^{2}+b_{i} P+c_{i}$

$\mathrm{F}_{\mathrm{T}} \quad$ : Total biaya pembangkitan (Rupiah)

$\mathrm{FC}_{\mathrm{i}}\left(\mathrm{P}_{\mathrm{i}}\right)$ : Fungsi biaya input-output dari pembangkit I (Rp/jam)

$a_{i}, b_{i}, c_{i}$ : Koefisien biaya dari pembangkit $\mathrm{i}$

$\mathrm{P}_{\mathrm{i}} \quad$ : Output pembangkit I (MW)

$\mathrm{N} \quad$ : Jumlah unit pembangkit

I : Indeks dari dispatchable unit

Jadi, seperti persamaan di atas, terlihat bahwa total biaya pembangkitan merupakan jumlah dari fungsi biaya tiap pembangkit. Masing-masing pembangkit memiliki batasan yang dirumuskan sebagai berikut :

$P_{\min } \leq P_{G} \leq P_{\max }$

Batas atas suatu pembangkit berhubungan dengan rating thermal stator generator. Sedangkan batas minimal suatu generator berhubungan dengan operasi boiler yang menghasilkan uap untuk menggerakan turbin. (Wood \& Wollenberg, 1996:29-32) 


\section{E. Permasalahan Emission Dispatch}

Permasalahan emission dispatch sama dengan permasalahan economic dispatch, namun tujuannya berbeda. Ketika economic dispatch lebih menekankan kepada faktor ekonomis, maka emission dispatch akan lebih menekankan pada reduksi kuantitas dari emisi yang dihasilkan tiap unit pembangkit. Berikut ini adalah persamaannya :

$F E_{i}\left(P_{i}\right)=d_{i} P^{2}+e_{i} P+f_{i}$

$\mathrm{FE}_{\mathrm{i}}\left(\mathrm{P}_{\mathrm{i}}\right)$ : Fungsi emisi dari pembangkit I (gram/jam)

$\mathrm{d}_{\mathrm{i}}, \mathrm{e}_{\mathrm{i}}, \mathrm{f}_{\mathrm{i}}:$ Koefisien emisi dari pembangkit $\mathrm{i}$

\section{F. Economic and Emission Dispatch}

Economic and Emission Dispatch adalah permasalahan optimasi dengan dua objektif, yaitu meminimalkan total biaya pembangkitan dan juga kuantitas dari emisi. Cara untuk menyelesaikan Economic and Emission Dispatch adalah dengan merubah permasalahan optimasinya dengan menjadikan single objective dengan menggunakan price penalty factor (Venkatesh et al.,2003). Berikut ini adalah persamaannya :

$F=W_{1} \cdot \sum_{i=1}^{N}(\mathrm{FCi})+W_{2} \cdot \sum_{i=1}^{N}\left(h_{i} \cdot \mathrm{FEi}\right)$

$h_{i}=\frac{\mathrm{FCi}}{\mathrm{FEi}}$

$W_{1}+W_{2}=1$

$\mathrm{F} \quad$ : Fungsi Tujuan

$F C_{i}$ : Biaya Pembangkitan Generator i

$F E_{i}$ : Banyak emisi yang dihasilkan generator $\mathrm{i}$

$h_{i}:$ Price Penalty Factor

$W_{1}$ : Bobot Untuk Biaya Pembangkitan

$W_{2}$ : Bobot Untuk Emisi Pembangkit

\section{G. Artificial Bee Colony Algorithm}

Koloni lebah buatan adalah algoritma yang ditemukan dan dikembangkan oleh Karaboga pada 2005 yang termotivasi oleh sifat dari lebah [11], [12]. Pada sistem $\mathrm{ABC}$, lebah akan terbang menuju daerah pencarian dan beberapa (employed and onlooker bees) memilih sumber makanan berdasarkan pengalaman dan juga informasi dari lebah lainnya dan juga mengatur posisi makanan. Beberapa (scouts) terbang dan memilih sumber makanan secara acak tanpa memiliki informasi sedikitpun. Jika jumlah nectar dari sumber makanan yang baru lebih banyak daripada sebelumnya, mereka akan mengingat posisi sumber makanan baru tersebut dan melupakan yang sebelumnya [12]. Maka dari itu, sistem ABC mengkombinasikan metode local search yang dibawa oleh employed and onlooker bees dan metode global search yang dibawa oleh onlookers and scouts bees yang berfungsi untuk menyeimbangkan antara eksplorasi dan eksploitasi.

Pada algoritma $\mathrm{ABC}$, koloni dari lebah terdiri dari 3 kelompok lebah, yaitu employed bees, onlooker bees and scout bees. Tahapan dari algoritma ABC adalah sebagai berikut :

- Inisialisasi

- REPEAT

- Penempatan employed bees di sumber makanan pada memori

- Penempatan onlooker bees di sumber makanan pada memori

- Mengirim scout bees ke daerah pencarian untuk menemukan sumber makanan baru
- Mengingat sumber makanan terbaik yang ditemukan sejauh ini

- UNTIL (sampai iterasi menyentuh maksimal)

Pada algoritma ABC, setiap siklus terdiri dari 3 tahap, yaitu memindahkan employed and onlooker bees menuju sumber makanan, menghitung jumlah nektar sumber makanan dan menetapkan scout bees dan memindahkan mereka secara acak menuju kandidat sumber makanan. Pada kasus ini, sumber makanan merepresentasikan calon-calon solusi yang dioptimasi.

Pada algoritma artificial bee colony, penentuan lokasi sumber makanan mula-mula akan ditentukan dengan perumusan sebagai berikut :

$X_{i j}=X_{j \text { min }}+\operatorname{rand}(0,1)\left(X_{j \max }-X_{j \text { min }}\right)$

Dimana $X_{j \text { min }}$ adalah batas bawah dari komponen ke $\mathrm{j}$ dan $X_{j} \max$ adalah batas atas dari komponen ke $\mathrm{j}$, sedangkan $X_{i j}$ adalah kemungkinan solusi ke i dari komponen ke $\mathrm{j}$.

Ketika employed bees mendatangi sumber makanan $X_{i j}$, maka dia akan mengubah posisi dari sumber makanan berdasarkan informasi local yang ada disekitarnya saat itu. Sehingga lokasi sumber makanan yang baru pun dapat diperoleh dengan perumusan sebagai berikut :

$V_{i j}=X_{i j}+\theta_{i j}\left(X_{i j}-X_{k j}\right)$

Dimana $V_{i j}$ adalah posisi baru dari sumber makanan ke-I untuk komponen ke-J, sedangkan $X_{i j}$ adalah posisi lama dari sumber makanan ke-I untuk komponen ke-J. I $=1,2, \ldots, \mathrm{SN} ; \mathrm{J}=1,2, \ldots, \mathrm{n} ; \mathrm{k}=1,2, \ldots, \mathrm{SN}$. Dimana $\mathrm{SN}$ adalah jumlah dari lebah pekerja.

\section{H. Modified Artificial Bee Colony Algorithm}

Pada struktur proses, algoritma modified artificial bee colony tidak berbeda dengan metode sebelumnya, namun terdapat modifikasi pada proses penentuan sumber makanan yang baru.

Akay dan Karaboga [13] memodifikasi sistem ABC dengan mengontrol frekuensi pengacakan dalam mencari lokasi sumber makanan baru. Untuk melakukan hal ini, maka akan digunakan modification rate (MR). Dengan tujuan untuk menghasilkan kandidat posisi sumber makanan, persamaan (9) akan dimodifikasi menjadi berikut :

$V_{i j}=\left\{\begin{array}{c}X_{i j}+\theta_{i j}\left(X_{i j}-X_{k j}\right), \text { if } R_{i j} \leq M R, \text { Else } \\ X_{i j}\end{array}\right\}$

Dimana $R_{i j}$ adalah angka yang terdistribusi secara acak Antara range $[0,1]$. MR adalah modification rate yang mempunyai nilai antara 0 sampai dengan 1 .

Untuk mengatur keberagaman dari solusi yang didapat, nilai $\theta_{i j}$ dapat diatur sesuai dengan kebutuhan. $\theta_{i j}$ memiliki nilai antara -1 sampai dengan 1. Namun pada modified artificial bee colony nilai ini dapat diatur sesuai dengan keinginan antara -SF sampai dengan SF. Nilai SF ini ditentukan sebelum program dijalankan. Nilai SF yang kecil akan menyebabkan pencarian solusi terbaik berjalan dengan step yang kecil, tentunya hal ini akan membuat konvergensi menjadi lama. Sedangkan nilai SF yang besar akan mempercepat pencarian solusi terbaik tetapi akan mereduksi tingkat eksploitasi dari proses pengacakan.

Pada tugas akhir ini, $X_{i j}$ dapat dianggap sebagai kemungkinan solusi ke i dari generator ke j. $X_{j \text { min }}$ adalah batas bawah dari generator ke $\mathrm{j}$ dan $X_{j \text { max }}$ adalah batas 
atas dari generator ke j. Sedangkan $V_{i j}$ adalah solusi baru ke-I untuk generator ke-J.

\section{ECONOMIC AND EMISSION DISPATCH MENGGUNAKAN MODIFIED ARTIFICIAL BEE COLONY ALGORITHM}

\section{A. Data Masukan}

Data yang dibutuhkan dalam pengerjaan Economic and Emission Dispatch dengan menggunakan MABCA terdiri dari :

- Data Beban

Data beban terdiri dari beban pada pukul 13.00 dan pada pukul 19.00 yang akan ditanggung oleh 17 unit pembangkit termal dan 3 unit PLTA yang dikondisikan bekerja secara maksimal pada sistem jamali $500 \mathrm{kV} 2021$.

- Data Pembangkitan

Data pembangkitan ini berisi tentang kapasitas maksimal dan minimal dari masing-masing unit pembangkit.

- Data Fungsi Biaya

Data fungsi biaya berisi fungsi biaya pembangkitan pada masing-masing pembangkit.

- Data Fungsi Emisi

Data fungsi emisi berisi fungsi emisi yang diakibatkan oleh pembakaran bahan bakar pada masing-masing pembangkit listrik termal.

B. Simulasi MABCA untuk Menyelesaikan Economic and Emission Dispatch

Prosedur standar untuk menerapkan MABCA adalah sebagai berikut :

1. Inisialisasi input program dan input dari plant yang akan dioptimasi. Input program berupa banyaknya populasi, banyak sumber makanan, maksimal nilai limit, nilai modification rate, scaling factor dan maksimal iterasi yang akan dijalankan. Sedangkan input dari plant adalah banyaknya unit generator, nilai cost function dan emission function dan total beban yang diminta.

2. Penentuan calon-calon kandidat makanan yang akan dibandingkan para lebah, makanan adalah representasi dari daya output generator yang nantinya akan dioptimasi.

3. Selanjutnya calon makanan akan diperiksa satu persatu dan akan diambil informasinya oleh lebahlebah. Nantinya lebah akan menentukan apakah sumber makanan tersebut perlu di update lokasinya atau tidak dan akan diperiksa kondisinya, melanggar batasan yang ada atau tidak.

4. Setelah itu setiap kandidat makanan akan dihitung biaya pembangkitannya dan akan dihitung nilai fitness dari masing- masing kandidat yang ada. Kandidat makanan dengan biaya termurah akan disimpan untuk sementara waktu yang nantinya akan dibandingkan dengan calon kandidat terbaik dari iterasi selanjutnya.

5. Proses ini akan berlangsung secara terus menerus dan akan berhenti jika iterasi maksimum tercapai. Ketika iterasi maksimum tercapai, maka daya output generator dengan biaya pembangkitan termurah akan ditampilkan

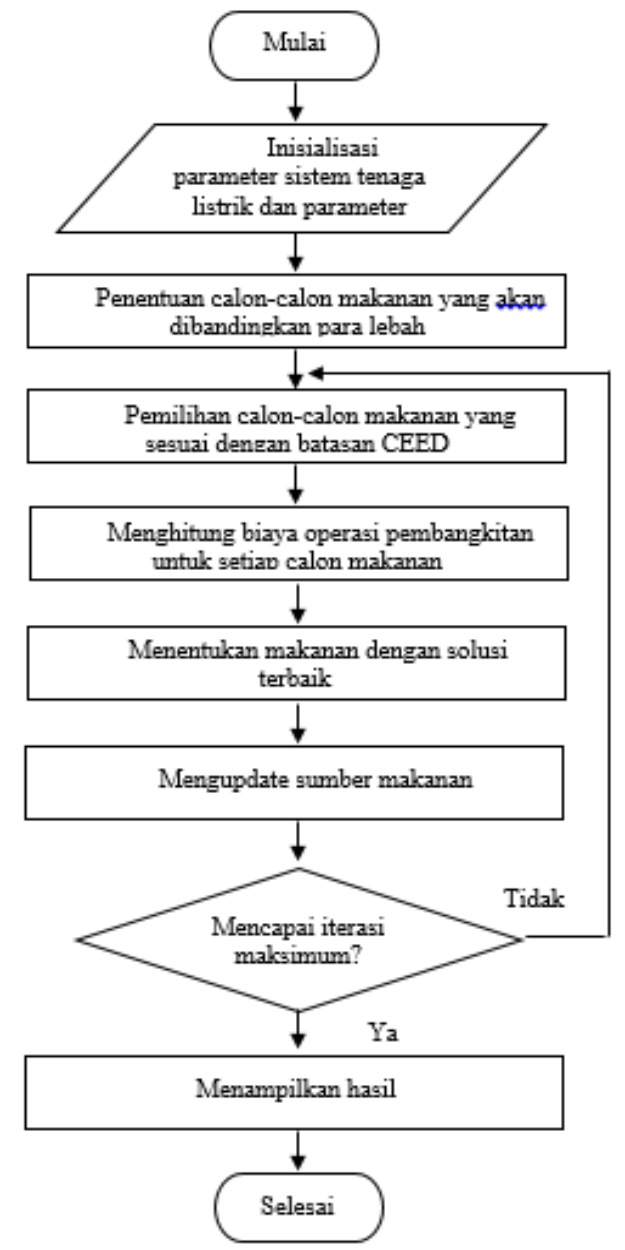

Gambar 4. Diagram Alir Modified Artificial Bee Colony Algorithm

\section{HASIL PENGUJIAN DAN ANALISIS}

\section{A. Data Sistem 500 kV Jawa Bali}

Pada tugas akhir ini menggunakan sistem $500 \mathrm{kV}$ Jawa Bali yang saling terkoneksi sehingga lebih efektif dan memiliki keandalan tinggi. Terlihat pada tabel 3.3, Sistem $500 \mathrm{kV}$ Jawa Bali 2021 mempunyai 20 pembangkit yang terdiri dari 17 pembangkit termal dan 3 PLTA. PLTA akan dioperasikan secara optimal dalam menyuplai beban dan sisanya akan ditanggung oleh pembangkit termal. Single Line Diagram sistem $500 \mathrm{kV}$ Jawa Bali dapat dilihat pada gambar 5 .

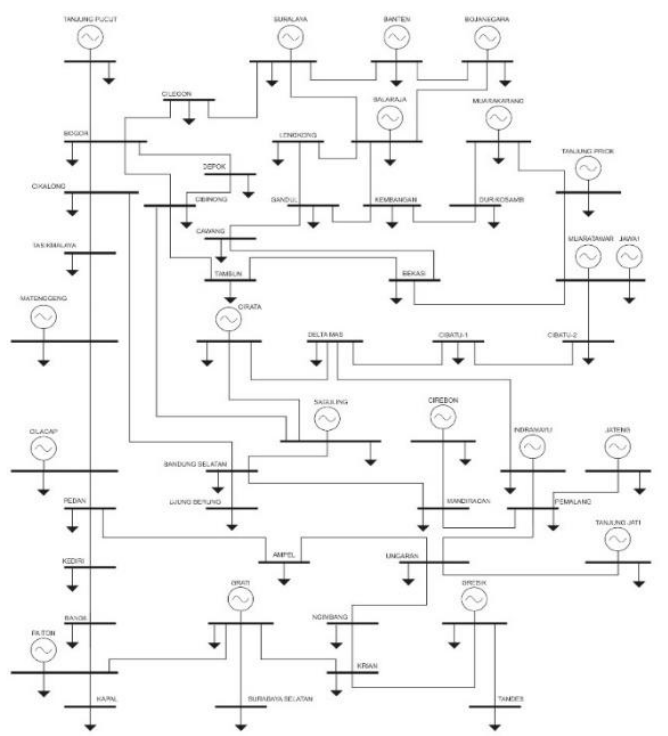

Gambar 5. Single line diagram Sistem 500 kV Jawa Bali 2021. 
TABEL 1. Data Beban Sistem 500 KV JaWA Bali 2021

\begin{tabular}{cc}
\hline \hline Pukul & Beban (MW) \\
\hline 13.00 & 39587 \\
19.00 & 39983 \\
\hline
\end{tabular}

Data pembangkit sistem $500 \mathrm{kV}$ jawa bali 2021 adalah sebagai berikut :

TABel 2. DATA PEMBANGKIT PADA Sistem 500 KV JAWA BaLi 2021

\begin{tabular}{ccc}
\hline Pembangkit & P Min (MW) & P Max (MW) \\
\hline Suralaya & 1610 & 4200 \\
Banten & 690 & 1725 \\
Bojanegara & 800 & 2000 \\
Balaraja & 800 & 2000 \\
Muarakarang & 848 & 2119 \\
Priok & 1149 & 2872 \\
Muaratawar & 1080 & 2700 \\
Matenggeng & 360 & 900 \\
Paiton & 1886 & 4714 \\
Jawa 1 & 640 & 1600 \\
Cirata & 403 & 1008 \\
Saguling & 696 & 1740 \\
Cirebon & 824 & 2060 \\
Jateng & 760 & 1900 \\
Indramayu & 1060 & 2650 \\
Tanjung Jati & 1856 & 4640 \\
Gresik & 1216 & 3040 \\
Tanjung Pucut & 1200 & 3000 \\
Grati & 546 & 1365 \\
Cilacap & 1436 & 3589 \\
\hline \hline
\end{tabular}

B. Simulasi Modified Artificial Bee Colony Algorithm Pada Economic and Emission Dispatch

Parameter yang digunakan dalam mengaplikasikan MABCA dalam menyelesaikan CEED pada sistem 500 kV Jawa Bali ditunjukkan pada tabel 3.

Tabel 3. Parameter Modified Artificial Bee Colony ALGORITHM

\begin{tabular}{cccccc}
\hline \hline Population & Foods & Limit & Iterasi & MR & SF \\
\hline 50 & 25 & 100 & 1000 & 0.8 & 3 \\
\hline \hline
\end{tabular}

Pada simulasi, nilai $\mathrm{W} 1$ dan $\mathrm{W} 2$ ditetapkan sebagaimana dapat dilihat pada tabel 4.

\begin{tabular}{ccc} 
TABEL 4. Nilai Pembobotan UntUK SimUlas \\
\hline \multicolumn{1}{c}{ Kasus } & W1 & W2 \\
\hline 1 & 1 & 0 \\
2 & 0.75 & 0.25 \\
3 & 0.5 & 0.5 \\
4 & 0.25 & 0.75 \\
5 & 0 & 1 \\
\hline
\end{tabular}

Pada saat kasus 1, nilai pembobotan lebih ditekankan pada faktor ekonomis daripada memprioritaskan pereduksian kuantitas emisi. Pada saat kasus 3, nilai pembobotan bernilai seimbang, artinya biaya pembangkitan dan juga pengurangan kuantitas emisi sama-sama diprioritaskan. Sedangkan Pada saat kasus 5, nilai pembobotan lebih ditekankan pada pengurangan emisi daripada mementingkan faktor ekonomis. Hasil simulasi untuk berbagai jenis kasus dan beban, dapat dilihat pada tabel 5 dan tabel 6 .

\begin{tabular}{ccc}
\multicolumn{3}{c}{ TABel 5. TOTAL BIAYA DAN EMISI PADA PUKUL 13.00 } \\
\hline \hline Kasus & Cost (Rp/jam) & Emisi (ton/jam) \\
\hline 1 & 83.470 .609 .760 & 39.782961956 \\
2 & 83.685 .997 .247 & 39.319061850
\end{tabular}

\begin{tabular}{|c|c|c|}
\hline 3 & 83.948.331.253 & 38.623552520 \\
\hline 4 & 84.090 .517 .873 & 38.601881113 \\
\hline 5 & 84.139 .156 .532 & 38.593241220 \\
\hline \multicolumn{3}{|c|}{ TABEL 6. TOTAL BIAYA DAN EMISI PADA PUKUL 19.0} \\
\hline Kasus & Cost (Rp/jam) & Emisi (ton/jam) \\
\hline 1 & 84.400 .668 .764 & 39.881 .620 .201 \\
\hline 2 & 84.479 .839 .469 & 39.615512115 \\
\hline 3 & 84.560 .768 .028 & 39.482 .508 .016 \\
\hline 4 & 84.719 .373 .881 & 39.260819740 \\
\hline 5 & 84.836 .319 .104 & 39.012 .719 .831 \\
\hline
\end{tabular}

\section{Hubungan Biaya Pembangkitan dan Emisi}

Pada tabel 5 dan tabel 6 dapat dilihat jika nilai pembobotan W1 dan W2 akan berpengaruh pada biaya pembangkitan dan besarnya emisi yang dihasilkan. Jika nilai W1 semakin kecil dan nilai W2 semakin besar, maka biaya pembangkitan akan semakin besar, namun emisi yang dihasilkan akan semakin kecil, sebaliknya jika nilai W1 semakin besar dan nilai W2 semakin kecil, maka biaya pembangkitan akan semakin kecil namun emisi yang dihasilkan akan semakin besar. Grafik hubungan antara biaya pembangkitan dan emisi dapat dilihat pada gambar 6 dan gambar 7 .

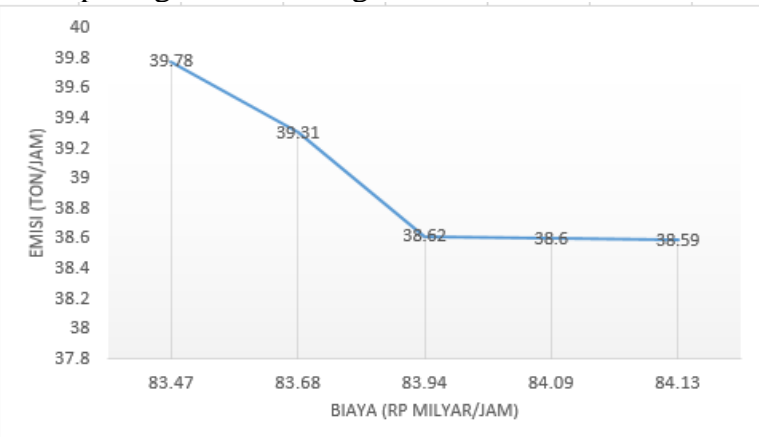

Gambar 6. Grafik Hubungan Biaya Pembangkitan dan Emisi Pukul 13.00

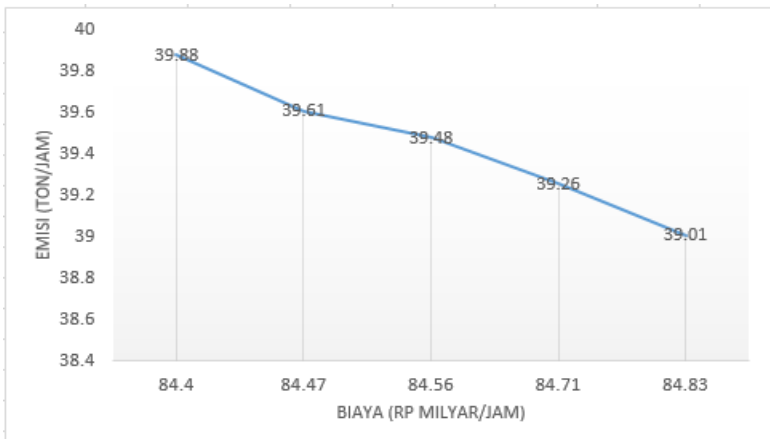

Gambar 7. Grafik Hubungan Biaya Pembangkitan da) Emisi Pukul 19.00

\section{KESIMPULAN}

Berdasarkan hasil yang didapatkan dari simulasi dan analisis pada penelitian ini, maka dapat diambil beberapa kesimpulan sebagai berikut :

1. Besar biaya pembangkitan tergantung pada cost function dan emission function.

2. Hasil dari simulasi menunjukkan bahwa faktor pembobotan berpengaruh kepada biaya pembangkitan. Jika faktor pembobotan lebih diprioritaskan pada faktor ekonomis, maka biaya pembangkitan akan murah, namun memiliki nilai emisi yang tinggi, begitu pula sebaliknya. 
3. Faktor pembobotan memiliki nilai mulai dari 0 sampai dengan 1. Jika nilai pembobotan ditentukan 1 dan 0 , maka dapat dikatakan bahwa faktor ekonomis lebih diutamakan. Jika pembobotan ditentukan 0 dan 1, maka dapat dikatakan bahwa faktor emisi lebih diutamakan. Pada Hasil simulasi yang telah dilakukan, dapat terlihat bahwa nilai pembobotan yang paling efektif untuk faktor ekonomis dan faktor emisi adalah ditentukan dengan nilai 0.5 dan 0.5 , hal ini menandakan bahwa faktor ekonomis dan emisi sama-sama diprioritaskan.

\section{DAFTAR PUSTAKA}

[1] Hadi Saadat, "Power System Analysis," WCB McGraw-Hil, New York, 1999

[2] Allen J. Wood and Bruce F, Wollenberg. "Power Generation, Operation and Kontrol". John Wiley \& Sons, Inc., 1996.

[3] Danaraj, R.M.S. dan Gajendran, F.,"Qtuadratic Programming Solution to Emission and Economic Dispatch Problems," Journal of the Indian Institute of Engineers (India), vol.86, pp.129-132, September 2005.

[4] Devi, A.L. dan Krishna, O.V., "Combined Economic and Emission Dispatch Using Evolutionary Algorithms - A Case Study," ARPN Journal of Engineering and Applied Sciences," vol.3 no.6, pp.28-35, Desember 2008.

[5] Noman N, Iba H. Differential evolution for economic load dispatch problems. Electr Power Syst Res 2008;78(3):1322-31.

[6] Karaboga D, Akay B. A comparative study of artificial bee colony algorithm. Appl Math Comput 2009;214(1):108-32.

[7] Karaboga D, Basturk B. A powerful and efficient algorithm for numerical function optimization: artificial bee colony (ABC) algorithm. J Global Optim 2007;39(3):459-71.

[8] Karaboga D, Akay B. A modified Artificial Bee Colony (ABC) algorithm for constrained optimization problems. Appl Soft Comput 2011;11(3): 3021-31.
[9] B Akay, D Karaboga. A Modified Artificial Bee Colony Algorithm for Real-Parameter Optimization. Information Sciences. 2012; 192; 120-142.

[10] Gao WF, Liu SY, Huang LL. A global best artificial bee colony algorithm for global optimization. J Comput Appl Math 2012;236(11):2741-53.

[11] D Karaboga, B Basturk. On the Performance of Artificial Bee Colony (ABC) Algorithm. Applied Soft Computing.2008; 8(1): 687-697.

[12] D Karaboga, B Akay. Artificial Bee Colony (ABC), Harmony Search and Bees Algorithms on Numerical Optimization. Proceedings of IPROMS 2009 Conference. 2009: $1-6$.

\section{BIOGRAFI PENULIS}

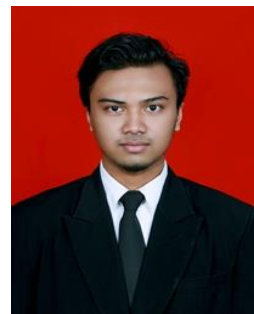

Dio Adya Pratama lahir di Surabaya, Jawa Timur pada tanggal 8 Juli 1993. Penulis merupakan anak pertama dari tiga bersaudara. Penulis menempuh pendidikan dasar di SDN Kranggan IV Mojokerto tahun 1999 - 2005, SMPN 1 Mojokerto tahun 2005 2008, SMAN 1 Puri Mojokerto pada tahun 2008 - 2011. Kuliah diploma di ITS dan lulus pada tahun 2014, kemudian dilanjutkan dengan kuliah sarjana setelah lulus dari pendidikan diploma. Penulis adalah orang yang ramah dan suka bercanda. Selama menjadi mahasiswa, tidak sedikit kegiatan yang diikuti, mulai dari mengikuti pelatihan pengembangan diri sampai dengan kegiatan open recruitment. 